\title{
Hair Loss in Youngsters
}

\section{Rajesh Rajput*}

Consultant Hair Transplant Surgeon \& Trichologist at Hair Restore, Mumbai, India

*Corresponding author: Dr. Rajesh Rajput, Consultant Hair Transplant Surgeon \& Trichologist at Hair Restore, Mumbai, India, Mumbai, India, Tel: +91-2267586688; Email: drrajeshrajput@gmail.com

Received date: April 23, 2018; Accepted date: April 30, 2018; Published date: May 05, 2018

Copyright: $\odot 2018$ Rajput R, This is an open-access article distributed under the terms of the Creative Commons Attribution License, which permits unrestricted use, distribution, and reproduction in any medium, provided the original author and source are credited.

Citation: Rajput R (2018) Hair Loss in Youngsters. J Gen Pract (Los Angel) 6: 355. doi:10.4172/2329-9126.1000355

\section{Short Communication}

Hair loss which was seen after the age of 45 years or more is now seen at much younger age, even in teenagers. Dr Rajesh Rajput at Hair Restore who is honoured to be Fellow of the International Society of Hair Restoration Surgeons and an International Certified Trichologist, talks about the current research in this field. The previous generations faced stress only after the age of 30-40 years [1]. Youngsters today face competitive life and stress on multiple fronts right since school days. Stress has become a part of routine life. Lack of inclination towards sports and good breathing exercise is also contributing to slow physical growth and poor hair quality. Young growing age needs very good nutrition in their formative years of life. Instead there is a trend towards eating less and neglecting nutrition.

There is attraction to have sugar foods and processed foods. Food is chosen by artificial tastes, presentation, colour, not by nutritional value. Researchers call this the hidden hunger which is never quenched. Restricted eating has become a social norm. Kids in 8th and 9th class in school are dieting. Fad diets, high protein, no carbs, fat free diet causes predicted deficiencies [2].

Raising exposure to pollution in the air, water, insecticides, pesticides, fertilizers in crops and fruits are further adding to the toxic burden on the body. Important nutrients in the body are wasted in fighting these chemicals leaving nothing for growth and repair.

Detoxification of the body repair and regeneration are functions achieved during sleep. Late nights and reduced sleeping hours lead to incomplete clearance of toxins from the body and partial repair of important vital systems leaving the hair growth as optional. Body deals with the insufficiencies by discontinuing hair growth and preserves the efficiency of important vital systems [3].

Low iron, calcium, fat soluble vitamins are compensated by stopping hair growth and not making the hair. It is a state of compensated failure.

We easily blame hormones and hereditary for hair loss, but the hair loss seen today is not hormonal. This can be successfully corrected by strengthening the hair roots with nutritional supplements and strengthening the hair roots. Strong hair roots can stand against any cause. The treatment of hair loss does not require use of anti-hormones and enzyme blockers. Antioxidants and vitamins can effectively fight stress. We not only control hair loss but also grow 30\% more new hair with scalp applications and nutritional supplements within 2 months without any side effects [4]. The new vitamin based treatment has been published internationally. The Hair Fact therapy is effective in men and women at any age and any type or grade of hair loss (Figure1).

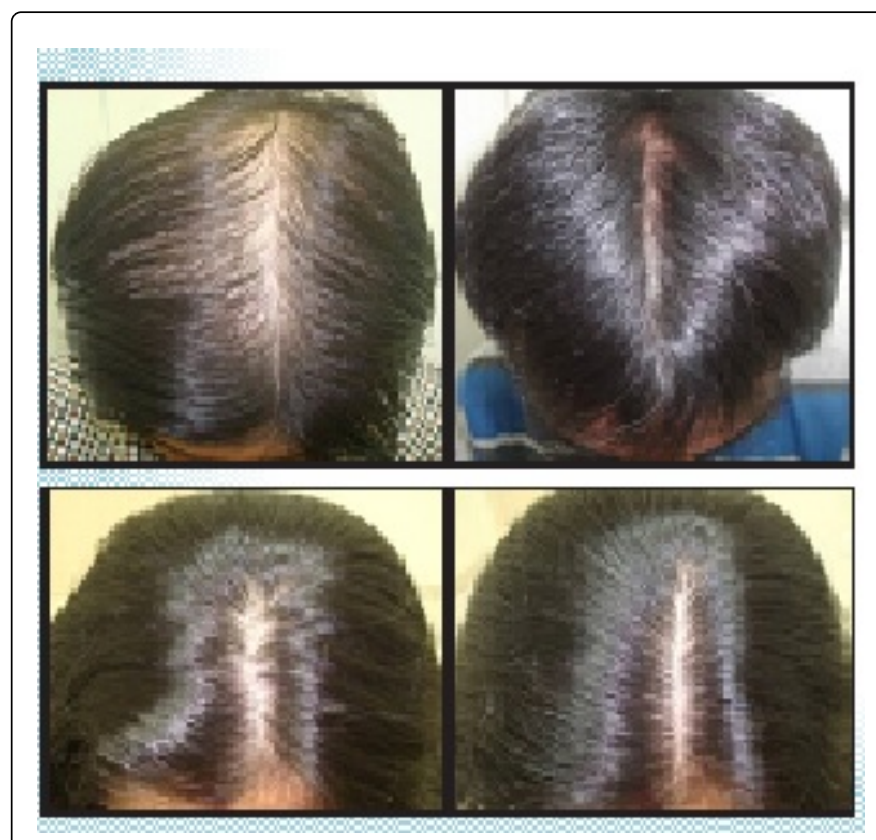

Figure 1: Before and after results of hair fact therapy.

\section{Hair loss at early age is not Hormonal}

- Ensure balanced nutrition

- No high protein, no carb free, no fat free diet

- Have at least 10 glasses of water

- Have minimum 6 hours of sleep

- Have 40 minutes of any exercise or sports activity of your choice

- Wash your scalp regularly at least three times a week

\section{References}

1. Hoffmann R, Happle R (2000) Current understanding of androgenetic alopecia. Part II: clinical aspects and treatment. Eur J Dermatol 10: 410-7.

2. Rinaldi F (2008) Pollution, scalp and hair transplants. Hair Transplant Forum International 18: 227.

3. Rajput R (2015) Understanding hair loss due to air pollution and the approach to management. Hair Ther Transplant 5: 133.

4. Botchkarev VA (2003) Stress and the hair follicle: Exploring the connections. Am J Pathol 162: 709-712. 